\title{
PROGRAM KEMITRAAN MASYARAKAT STIMULUS (PKMS) PADA YAYASAN CINDERELLA KOTA BATAM
}

\section{STIMULUS COMMUNITY PARTNERSHIP PROGRAM (PKMS) ON THE CINDERELLA FOUNDATION OF BATAM CITY}

\author{
Sri Langgeng Ratnasari ${ }^{1 *}$, Gandhi Sutjahjo ${ }^{2}$ \\ 1 (Prodi Magister Manajemen, Program Pascasarjana, Universitas Riau Kepulauan, Indonesia) \\ ${ }^{2}$ (Prodi Sistem Informasi, Fakultas Teknik, Universitas Batam, Indonesia) \\ ${ }^{1}$ e-mail sarisucahyo@yahoo.com ${ }^{2}$ e-mail gandhi.sucahyo@yahoo.com
}

\begin{abstract}
Abstrak
Pengabdian Pada Masyarakat melalui Program Kemitraan Masyarakat Stimulus (PKMS) yang didanai oleh Kemerintek Dikti Tahun 2019 ini bertujuan untuk pemberdayaan perempuan, anak jalanan, dan penyandang cacat. Pemberdayaan perempuan khususnya pada tahanan perempuan di Lembaga Pemasyarakatan (LAPAS) Baloi Kota Batam, perempuan single parent yang tidak mampu, dan pemberdayaan anak jalanan yang tergabung di Yayasan Cinderella Kota Batam. Pengabdian kemitraan masyarakat stimulus (PKMS) ini menggunakan metode studi literatur dengan menggunakan analisis kualitatif dan deskriptif, serta metode andragogi. Metode andragogi adalah metode yang menekankan dan menerapkan Program Tindak Partisipatif dari peserta melalui pelatihan, diskusi, kerja kelompok, dan demonstrasi lapangan pada seluruh kegiatan yang dilaksanakan. Pelaksanaan Program Kemitraan Masyarakat Stimulus (PKMS) ini dengan pendampingan, pemberdayaan, dan pelatihan meningkatkan kualitas pembuatan boneka dan pemasaran secara online. Hasil produk berupa boneka Cinderella didonasikan untuk penderita kanker, disabilitas mulai di Indonesia, negara-negara ASEAN, dan beberapa negara Eropa. Pelaksanaan Program Kemitraan Masyrakat Stimulus (PKMS) ini mendapatkan hasil berupa peningkatan kualitas pembuatan boneka Cinderella dan meningkatnya pendapatan Yayasan Cinderella Kota Batam dari pemasaran online yang digunakan kembali untuk membeli bahan dan biaya pembuatan Boneka Cinderella.
\end{abstract}

Kata kunci: Pemberdayaan Masyarakat, Pelatihan, Pemasaran Online, Perempuan, Disabilitas

\begin{abstract}
Community Service through the Stimulus Community Partnership Program (PKMS) funded by the Ministry of Higher Education in 2019 aims to empower women, street children and people with disabilities. Empowering women, especially women detainees at the Baloi Penitentiary (LAPAS) Batam City, single parent women who are unable, and empowering street children who are members of the Batam City Cinderella Foundation. Community Service Stimulation Partnership (PKMS) uses literary study method by using qualitative and descriptive analysis, and andragogy method. Andragogy method is a method that emphasizes and implements Participatory Action Programs from participants through training, discussion, group work, and field demonstrations on all activities carried out. The implementation of the Stimulus Community Partnership Program (PKMS) through mentoring, empowerment and training improves the quality of doll making and online marketing. The products in the form of Cinderella dolls are donated to cancer patients, with disabilities starting in Indonesia, ASEAN countries, and several European countries. The implementation of the Stimulus Community Partnership Program (PKMS) received results in the form of improving the quality of making Cinderella dolls and increasing the income of the Batam City Cinderella Foundation from online marketing which was reused to buy materials and the cost of making Cinderella dolls.
\end{abstract}

Keywords: Community Empowerment, Training, Online Marketing, Women, Disability 


\section{PENDAHULUAN}

Yayasan Cinderella Kota Batam didirikan pada tanggal 15 Januari 2013 oleh Ibu Lusi Efriyani Kiroyan, S.Sos., dengan salah satu latar belakangnya adalah untuk memberdayakan ratusan perempuan penghuni Lembaga Pemasyarakatan (LAPAS) Baloi Kota Batam, anakanak jalanan, dan perempuan single parent yang tidak mampu untuk membuat boneka Batik Cinderella, yakni sebuah boneka cantik berambut hitam dan menggenakan batik, Murni (2014).

Yayasan Cinderella Kota Batam sangat menolong perempuan penghuni Lembaga Pemasyarakatan (LAPAS) Baloi Kota Batam, karena yayasan ini dapat membantu mereka memperoleh penghasilan selama mereka menjalani hukuman. Penghasilan tersebut dapat digunakan untuk memenuhi kebutuhan sehari-hari selama mereka di LAPAS, seperti membeli pembalut pada saat haid, membeli pasta gigi dan sikat gigi, membeli sabun mandi, sabun cuci baju, shampoo, dan peralatan lainnya untuk kebutuhan sehari-hari (Best People Indonesia, 2016).

Yayasan Cinderella Kota Batam menyediakan tempat dan melakukan pemberdayaan anak-anak jalanan agar mereka berhenti menjadi anak jalanan dan mandiri, sehingga mereka dapat hidup layak seperti anak seusia mereka bebas berekspresi, dihargai, belajar dan bermain dengan riang, sampai dengan saat ini ada 23 anak jalanan yang menghuni rumah singgah dan rumah belajar ini. Yayasan Cinderella Kota Batam juga memberdayakan perempuan single parent yang tidak mampu bekerjasama dengan Dinas Pemberdayaan Perempuan dan Perlindungan Anak Kota Batam. Yayasan ini juga aktif dalam kegiatan sosial lainnya, (Cinderella from Indonesia Center, 2013).

Yayasan Cinderella Kota Batam melakukan kegiatan berupa membuat boneka batik Cinderella, menjahit, dan ketrampilan lainnya, disamping itu juga memberdayakan perempuan disabilitas dengan melibatkan mereka membuat boneka batik Cinderella, menyulam, dan ketrampilan lainnya. Hasil dari pembuatan boneka batik Cinderella digunakan untuk didonasikan pada penderita kanker dan disabilitas di Indonesia dan ASEAN. Hal ini dilakukan karena peminat boneka batik Cinderella dari masyarakat sangat minim dan sebagai solusi alternatif untuk memperoleh penghasilan dari donatur dari boneka batik Cinderella yang dihasilkan Yayasan Cinderella tersebut. Yayasan Cinderella mencari cara bagaimana 


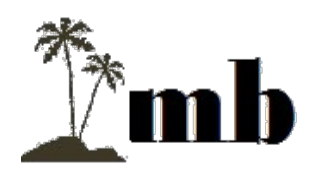

Minda Baharu, Volume 3, No 2 Desember 2019

https://www.journal.unrika.ac.id/index.php/MNDBHRU

Doi. 10.33373/jmb.v3i2.1963

P-ISSN 2656-0631; E-ISSN 2614-5944

Hal. 66-74

alternatif pemasaran lainnya yang bisa dilakukan bekerjasama dengan Universitas Riau Kepulauan dalam program Kemitraan Masyarakat Stimulus (PKMS) untuk meningkatkan penjualan kepada masyarakat umum dengan cara memberdayakan mahasiswa sebagai marketingnya. Hal ini mengacu pada ketentuan hibah PKMS dari Kemenristekdikti, Kemenristekdikti (2018).

\section{Permasalahan Mitra}

Permasalahan yang dihadapi Mitra dalam hal ini Yayasan Cinderella Kota Batam adalah pemasaran boneka Batik Cinderella kepada masyarakat umum. Menurut pemilik Yayasan Cinderella Kota Batam beberapa strategi sudah dilakukan, namun belum menunjukkan hasil yang memuaskan. Ada beberapa penolakan halus dari calon konsumen setelah mengetahui bahwa boneka batik Cinderella diproduksi oleh perempuan penghuni lembaga pemasyarakatan, perempuan single parent yang tidak mampu, anak jalanan, dan kaum disabilitas. Setelah mengetahui pembuat boneka Batik Cinderella, mereka enggan melakukan pembelian, karena dalam image mereka, boneka menjadi tidak menarik karena dibuat oleh orang-orang yang menurut pandangan mereka kurang baik.

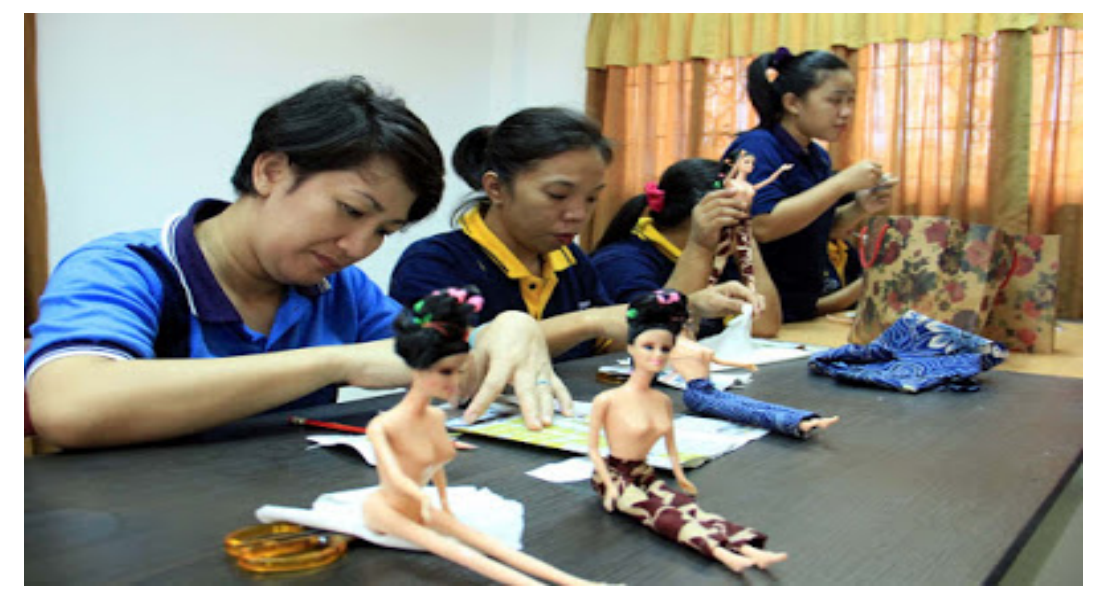

Figur 1. Pembuatan Boneka Batik Cinderella Napi di Lapas Baloi Batam

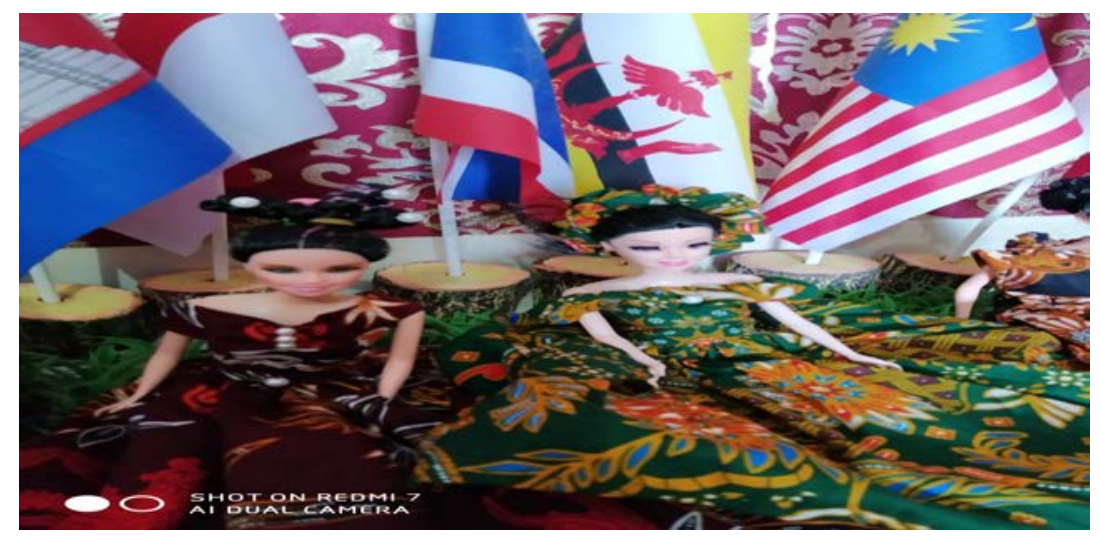


Figur 2. Boneka Batik Cinderella hasil karya Napi Perempuan LAPAS Baloi Kota Batam

\section{METODOLOGI}

Metode yang digunakan dalam kegiatan Program Kemitraan Masyarakat Stimulus ini menggunakan studi literatur dengan menggunakan analisis kualitatif dan deskriptif, serta metode andragogi. Metode andragogi adalah metode yang menekankan dan menerapkan Program Tindak Partisipatif dari peserta melalui pelatihan, diskusi, kerja kelompok, dan demonstrasi lapangan pada seluruh kegiatan yang melibatkan pihak terkait, dalam hal ini narapidana perempuan Lapas Baloi Kota Batam.

\section{PEMBAHASAN}

Berdasarkan permasalahan yang ada, maka solusi yang ditawarkan adalah melakukan peracangan penjualan secara online melalui Shopee.
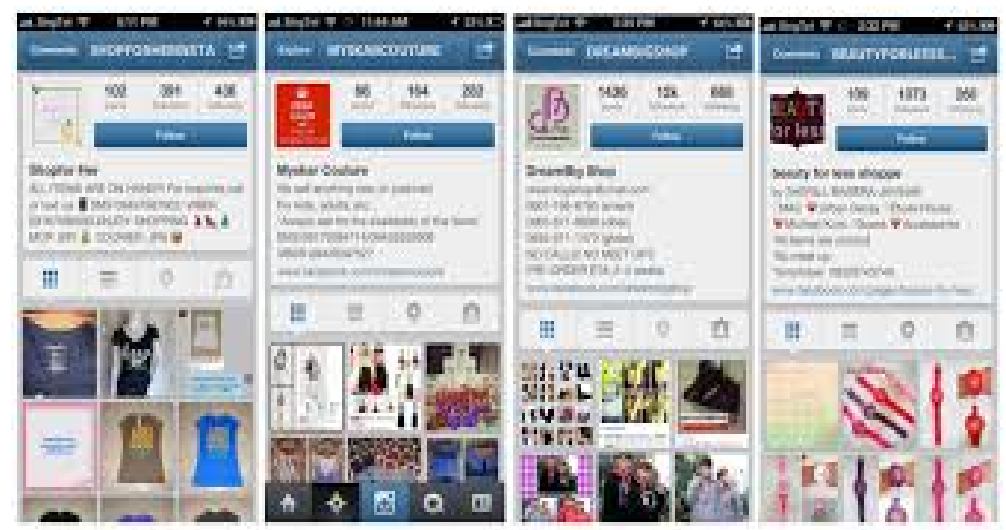

Figur 3. Penjualan online melalui Shopee

Online Shop, menurut Irwantoko, belanja online (online shop) merupakan proses pembelian barang/jasa oleh konsumen ke penjual atau realtime, tanpa pelayan dan melalui internet. Toko virtual ini mengubah paradigma proses membeli barang/jasa dibatasi oleh tembok, pengecer, atau mall. Hal ini dimaksudkan bahwa dalam penjualan tidak perlu harus bertemu penjual dengan pembeli secara langsung, tidak perlu menemukan wujud pasar secara fisik, namun hanya dengan menghadap layar monitor, dengan koneksi internet tersambung, kita sudah dapat melakukan interaksi jual/beli secara cepat dan nyaman, Arofah (2011).

Hasil survey terakhir (Desember 2011) menunjukan bahwa 36\% dari seluruh transaksi perdagangan yang terjadi di Indonesia di lakukan secara online atau online shop. 
Diperkirakan 80\% dari transaksi online tersebut ternyata dilakukan oleh bisnis online berskala Mikro Kecil (UMK), Astuti (2008).

Omset bisnis online berskala UMK ini mulai dari 2juta per bulan, hingga puluhan juta perbulan, namun karena jumlahnya yang sangat banyak, maka omset keseluruhan UMK online mampu mencapai 80\% dari keseluruhan transaksi online. (Logo, 2012). Di Indonesia sendiri, belanja online atau online shop mulai muncul sekitar tahun 2000an, dan sekarang toko online sudah menjamur dimana-mana. Apalagi dengan adanya dukungan media jejaring sosial seperti: facebook, twitter, line, bbm, ig yang dapat sangat berguna untuk mempromosikan produk yang ingin dijual/dibeli. Media sosial inilah yang merupakan salah satu media yang membuat berbelanja online semakin mudah terjadi.

Pada awal kemunculannya di Indonesia, belanja online hanya digunakan oleh masyarakat kalangan atas, karena belanja online membutuhkan komputer, jaringan internet dan kartu debet untuk melakukan transaksi jual/beli tersebut. Namun seiring berjalannya waktu, dikarenakan oleh faktor kenyamanan dan kecepatan, sekarang mulai dari ibu-ibu pejabat, sampai mahasiswa/mahasiswi banyak yang memanfaatkan berbelanja dengan online.

Sebelum dilakukan pemasaran boneka batik Cinderella secara online, maka harus dilakukan Analisis Terhadap Lingkungan Umum, yakni analisis lingkungan eksternal. Analisis lingkungan eksternal bertujuan untuk mengetahui ancaman dan peluang. Ancaman adalah suatu kondisi dalam lingkungan umum yang dapat menghambat usaha-usaha perusahaan untuk mencapai daya saing strategis, sedangkan peluang adalah kondisi dalam lingkungan umum yang dapat membantu perusahaan mencapai daya saing strategis. Proses yang dilakukan secara kontinyu untuk melakukan analisis lingkungan eksternal adalah dengan melakukan pemindaian (scanning), pengawasan (monitoring), peramalan (forecasting), dan penilaian (assessing), Hakim (2013).

\section{Pemindaian}

Melalui pemindaian perusahaan mengidentifikasi tanda-tanda awal dari perubahan potensial dalam lingkungan umum, dan mendeteksi perubahan-perubahan yang sedang terjadi. Pemindaian lingkungan merupakan hal penting dan menentukan bagi perusahaan-perusahaan yang bersaing dalam lingkungan yang sangat tidak stabil, Hariningsih (2005).

2. Pengawasan 
Melalui pengawasan perusahaan mendeteksi perubahan dan trend-trend lingkungan melalui pengawasan yang berkelanjutan. Kritikal bagi pengawasan yang berhasil adalah kemampuan untuk mendeteksi makna dalam peristiwa-peristiwa lingkungan yang berbeda.

3. Peramalan

Pada peramalan, analis mengembangkan proyek-proyek yang layak tentang apa yang mungkin terjadi, dan seberapa cepat, perubahan-perubahan dan trend-trend itu dideteksi melalui pemindaian dan pengawasan.

4. Penilaian

Tujuan penilaian adalah untuk menentukan waktu dan signifikansi efek-efek dari perubahan-perubahan dan trend-trend lingkungan terhadap manajemen strategis suatu perusahaan. Selangkah lebih maju tujuan penilaian adalah untuk menspesifikasi implikasi pemahaman tersebut pada organisasi. Tanpa penilaian perusahaan dibiarkan dengan data-data yang menarik, tapi tidak diketahui relevansi kompetitiifnya.

Lingkungan umum adalah suatu lingkungan dalam lingkungan eksternal organisasi yang menyusun faktor-faktor tersebut pada dasarnya diluar dan terlepas dari operasi perusahaan, Dagigil (2011). Faktor-faktor tersebut antara lain:

1. Faktor Ekonomi

Faktor ekonomi mengacu pada sifat, cara dan arah dari perekonomian dimana suatu perusahaan akan atau sedang berkompetisi. Indikator dari kesehatan perekonomian suatu Negara antara lain adalah tingkat inflasi, tingkat suku bunga, defisit atau surplus perdagangan, tingkat tabungan pribadi dan bisnis, serta produk domestik bruto.

2. Faktor Sosial

Faktor sosial yang mempengaruhi suatu perusahaan mencakup keyakinan, nilai, sikap, opini yang berkembang, dan gaya hidup dari orang-orang di lingkungan mana perusahaan beroperasi. Faktor-faktor ini biasanya dikembangkan dari kondiasi kultural, ekologis, pendidikan, dan kondisi etnis, Lemhannas RI (2016).

3. Faktor Politik dan Hukum

Faktor politik dan hukum mendefinisikan parameter-parameter hukum dan bagaimana pengaturan perusahaan harus beroperasi. Kendala politik 
diberlakukan terhadap perusahaan melalui keputusan perdagangan yang wajar, program perpajakan, penentuan upah minimum, kebijakan polusi dan harga serta banyak tindakan lainnya yang bertujuan untuk melindungi karyawan, konsumen, masyarakat umum dan lingkungan. Beberapa tindakan politik dan hukum juga didesain untuk member manfaat dan melindungi perusahaan.

4. Faktor Teknologi

Kemajuan teknologi secara dramatis telah mengubah produk, jasa, pasar, pemasok, distributor, pesaing, pelanggan, proses manufaktur, praktik-praktik pemasaran dan posisi persaingan. Kemajuan teknologi dapat menciptakan pasar baru, perkembangan produk, dan lain sebagainya. Perubahan teknologi dapat mengurangi atau menghilangkan perbedaan biaya antar perusahaan, menciptakan proses produksi yang lebih singkat, menciptakan kelangkaan pada tenaga tehnikal serta mampu merubah nilai-nilai dan harapan para stake holders, Harianto (2004).

5. Faktor Demografi

Yang perlu diperhatikan oleh perusahaan menyangkut faktor demografi ini diantaranya adalah ukuran populasi, struktur umum, distribusi geografis, pencampuran etnis serta distribusi pendapatan.

Lingkungan industri adalah tingkatan dari lingkungan eksternal organisasi yang menghasilkan komponen yang secara normal memiliki implikasi yang relative lebih spesifik dan langsung terhadap operasional perusahaan.

Hal tersebut mempengaruhi dalam hal diantaranya:

1. Perubahan basis konsumen, yang dapat meningkatkan kekuatan pembeli

2. Keberagaman dalam karakteristik desain dan kualitas diantara pemain akan meningkatkan.

3. Persaingan

4. Pemain baru

\section{KESIMPULAN DAN SARAN}

Model implementasi berupa pelatihan, pendampingan, dan pemberdayaan masyarakat pada Yayasan Cinderella Kota Batam berjalan dengan baik. Dukungan mahasiswa dan 
masyarakat terhadap program pengabdian masyarakat sangat baik. Terjadi peningkatan pendapatan melalui pemasaran online pada Yayasan Cinderella Kota Batam.

Saran yang dapat diberikan dalam pengabdian masyarakat ini adalah: Memberdayakan masyarakat untuk peduli dan mau memberdayakan kaum marginal dan minoritas untuk kehidupan yang lebih baik khususnya di Yayasan Cinderella Kota Batam. Memberikan penyuluhan dan pelatihan secara berkala, minimum sebulan sekali untuk mengembangkan implementasi kegiatan pengabdian masyarakat Program Kemitraan Masyarakat Stimulus (PKMS).

\section{Ucapan Terima Kasih}

Pada kesempatan ini, kami mengucapkan terima kasih kepada:

1. DRPM Kemerintek Dikti yang telah memberikan pendanaan pada Program Kemitraan Masyarakat Stimulus ini.

2. Universitas Riau Kepulauan khususnya LPPM yang telah banyak membantu dalam terlaksananya PKMS ini.

3. Yayasan Cinderella Kota Batam yang telah bersedia menjadi Mitra PKMS.

4. LAPAS Perempuan, Kota Batam

5. Adik-adik mahasiswa Universitas Riau Kepulauan yakni Widia Prodi Akuntansi dan Rona Prodi Pendidikan Bahasa Inggris sebagai peneliti pembantu.

\section{REFERENSI}

Arofah,Y., (2011), Sistem Informasi Toko Online Branded, Tugas Akhir, Fakultas Matematika dan Ilmu Pengetahuan Alam, Universitas Gadjah Mada.

Astuti, W., (2008), Sistem Pemesanan Buku Online Di Toko Buku Sahabat Pena, Tugas Akhir, Fakultas Matematika dan Ilmu Pengetahuan Alam, Universitas Gadjah Mada.

Best People Indonesia, (2016). USIA EFRIYANI KIROYAN : Pendiri Cinderella From Indonesia Center Dan Batik Girls. Memberdayakan Napi Wanita, Anak Jalanan, Dan Single Parent Kurang Beruntung. https:// bestyoungindonesia.blogspot.com/2016/09/lusia-efriyani-kiroyan-pendiri. html

Cinderella from Indonesia Center, (2013). https://cinderellafromindonesiacenter. wordpress.com/2013/

Daqiqil, I, (2011), Framework Codeigniter2 Sebuah panduan dan best practice. 
Doi. 10.33373/jmb.v3i2.1963

Minda Baharu, Volume 3, No 2 Desember 2019

Hakim, L., (2013), Proyek Website Super wow dengan PHP dan JQuery, Lokomedia, Yogyakarta.

Harianto, K., (2004), Konsep dan Perancangan Database, ANDI, Yogyakarta

Hariningsih, (2005), Teknologi Informasi, Graha Ilmu, Yogyakarta.

Kemenristekdikti. (2018). Panduan Penelitian Dan Pengabdian Kepada Masyarakat Edisi XII. Kemenristekdikti. Jakarta.

Logo (2012). Transaksi Online UMK. Gramedia. Jakarta.

Lemhannas RI. (2016). Modul Bidang Studi Kepemimpinan. Lemhannas RI., Jakarta

Murni, S., (2014). Cinderella from Indonesia Centre Asuh 23 Anak Jalanan. Tribun news, Batam. 